\title{
A STUDY OF FEMALE IN CONTEXT TO DREAM VERSUS REALITY
}

\section{IN BHARATI MUKHERJEE'S JASMINE}

\section{Dr. Jagdish Joshi \\ \&}

\section{Ms. Surekha R. Patil}

\begin{abstract}
:
Female has been dominated by patriarchal society since ages. Her voice does not have any significance or importance in Indian society. Women have all potentialities and abilities like men; still they are not recognized or appreciated as equal to men. This is the predicament of women who confine women in restricted social codes and norms. Her individual self has no reorganization in the patriarchal society. Women's duties were confined to the specific areas especially household works. Her dreams never convert into reality due to the rigid mindset of patriarchal.
\end{abstract}

Bharti Mukherjee is one of the eminent female writers who write about women and the problems faced by them and so that we can say women are at the center of her texts. Bharati Mukherjee deals with the themes of Indian Women particularly the problem of cross-cultural predicament and crisis. Her work has helped to break the silence on some women's issues which were not discussed in the past due to the fear of prevailing attitude of patriarchy. To raise people's awareness, she writes particular about what she sees around her. She writes how the female protagonist tries to tackle the problem of loss of endeavors to assume a new identity in the U.S. She leaves her country to fulfill her dreams and wishes but reality was totally different. Mukherjee introduces us to the various changes that her novel's main protagonist Jasmine goes through, as she journeys from the world of rural Indian Punjab to that of America's Mid-West, discovering her American dream in the process. At last she realizes that self-independence is not to be an Indian or American but to be at peace with herself. 
Keywords: East, West, Cross-Cultural, Identity, self-independence, dream, reality, Crisis, womanhood, superstition, violence, Values.

\section{Full Research Paper}

A study of Female in context to Dream versus Reality in Bharati Mukherjee's Jasmine

Bharati Mukherjee is eminent writer who focused on female issues and raises voice against it. She belongs to the group of writers from the postcolonial Indian Diaspora. She was born in Kolkata, in a Brahmin family. She got her BA from the University of Kolkata, her MA from the University of Baroda, and then moved to the USA for study. She obtained another MA and a Doctorate at the University of Iowa. Mukherjee's works :The Tiger's Daughter1971, Wife-1975, Jasmine-1981, The Holder of the World-1993, Leave It To Me-1997, Desirable Daughters-2002, The Tree Bride-2004, short stories collections such as Darkness-1985, The Middleman and Other Stories-1988, A Father, non-fiction such as The Sorrow and the Terror: The Haunting Legacy or Air India Tragedy-1987, Political Culture and Leadership in India-1991, Regionalism in Indian perspective-1992 etc. Her literary work is the great contribution in Indian English Literature.

Bharati Mukherjee explores the meaning of life and gives it shape through her literary works. Various issues and problems related to women are at the central of in fictions of Mukherjee. She deals with the problems of the Indian immigrants mainly faced by women. She writes about the struggles and problems faced and tackled by Indian women. The problem of cross-cultural crisis and the factual condition versus reality is also one of the most well-known themes of her novels. Her novels reflect the nature and frame of mind of the present American Society as experienced by the Indian immigrants in America. Her novels express the desires and impulses of Indians and the problems of adaption, adjustment, survival and endurance. Bharati Mukherjee also depicts the cultural clashes and differences between the East and the West. She describes the experiences of a person who leaves her own culture and ethnicity and enters into another culture which is totally stranger to her and becomes conflict for her. 
The Novel Jasmine is about adaptation and adjustment and not a defeat. Bharati Mukherjee uses flash back and stream of consciousness technique. It is the story of a Punjabi rustic girl, Jyoti who turns later as Jasmine and Prakash. Prakash was an active, energetic and enthusiastic young man who enters in Jyoti's life as her husband. He was very clear about his dreams and desires and for that he has prepared future plan also. Already he has decided to go America for fulfillment of his wishes and desires. When Prakash prepares to go to America, Jyoti said, "I'll go with you and if you leave me, I'll jump into a well"(6). Prakash knows very well about his goals and its achievement process but Jyoti was not firm about her goal. For her to help Prakash to achieve his goal becomes ultimate goal of her. Actually that is the thought implanted in the mind of Indian woman to serve husband as god and support him in his every tasks. A woman has to accept, the path of her husband. Jyoti joyously sharing the ambition of her husband and looks forward to go to America. But this dream gets shattered by the murder of Prakash. She decides to go America and fulfill Prakash's mission and desire. She performs as "Sati" who was on the path of her husband. She grabs every opportunity to become American in possible manner.

Jasmine becomes Jase. In the process of fulfillment desires of husband, she lost her specific identity and converts herself into different roles as the demand of time and situation. At the end she kills Sukhawinder, who killed Prakash and took the revenge of the death of her husband. Sukhawinder was responsible for the death Prakash. He had had spoiled their happy lives and shattered the dreams to achieve the specific goal. The manifold facets or roles played by Jasmine as Jase and Jase assault the power in woman, who turns as a new woman. Jasmine has broken away from the restraints of social order, gender and family. Gradually Jasmine has learnt to live not for her husband or for her children but herself. Jasmine is a survivor, a rebellion and an adaptor.

Sometimes to fulfill some dreams, our reality goes far away from us:

He wanted to break down the Jyoti I'd been in Hasnapur and make me a new kind of city woman. To break off the past, he gave me a new name: Jasmine. He said, "you are small and sweet and heady, my jasmine. You'll quicken the whole world with your perfume." Jyoti, Jasmine: I shuttled between identities. (77) 
The narrator in Jasmine also recognized as Jyoti, Jase or Jane, and passes through different conditions and countries until she finally seems to have found a place to rest. Throughout the novel, Jasmine experiences frequent situations and conditions that bring violence and problems with them and hurts her. She is not all the time the issue of these situations, but directly or indirectly they are always associated with her. It is not only physical violence and brutality experienced, but also psychological aggression that influences Jasmines supplementary approach of life and forces her to be reborn as a different person. Mukherjee has drawn the rough pictures of violent which replicate the psychological twinge that comes with the changes of culture and society.

Inspite of the power and determination, she was threatened by dangers, challenges and many barriers and problems in her real life. She had desires, dreams and fantasies in her life but the reality was far away from that. Our society is full of paradoxes and contradictions. The female is considered to be a peripheral member of the family. Throughout her lifetime she is unable to decide her roots and this leads to her insecurity. She offends her father by disclosing her ambition:

I want to be a doctor and set up my own clinic in a big town. Like the moustaced doctor in the bazaar clinic, I wanted to scrape off cataracts, fit plastic legs on stumps, work miracles. My father grasped, "The girl is mad! I'll write in the back of the dictionary: the girl is mad!" (51)

Everything happens as per the wish of patriarchal society. Everything is discriminated on the basis of sex: male and female. Specific duties are assigned to females like maintaining the home, caring child and serving a husband. She does not have any right to see dreams or decides her wishes beyond assigned duties. Even woman has to learn to live her life according to her husband's desires. Without him she is like nobody to all. She has to confine her world around him only. A woman is supposed to bear her exploitation and suffering silently as her fate instead of raising her voice against it. Acceptance of fate whether it's cruel or atrocious, they have to live it throughout without any complain which is the part of women's social upbringing. An Indian woman is yet to seek identity 
as a human being with equal status in the family in which she is born and in the family to which she is given in marriage.

Jasmine thinks of a girl Vimla, because her marriage was the fanciest the village anyone had ever seen. Her father gave away a zippy red Maruti and a refrigerator in the dowry. When she was twenty one her husband died of typhoid, and at twenty two she do used herself with kerosene and flung herself on a stove, shouting to the god of death, "Yama, bring me to you."(15). After the death of husband woman doesn't have any dream and desire, everything is shattered into the pieces. Woman cannot think to live life without husband in society. Because that is the pre mind set of woman in which she has learnt that husband is everything to her after marriage.

Jasmine opens with an astrologer's foretelling of Jyoti's future, of her early widowhood and exile."No," she shouts, "You're a crazy old man (5). She doesn't believe it. Here we can see Jasmine as a rebellion who denies others' order or forecast by saying that is her life and her decision. But the man hits her and she falls on the ground, bits her tongue and gets a scar on the forehead. She shouted

"It's not a scar, it's my third eye. In the stories that our mother recited, the holiest sages developed an extra eye right in the middle of their foreheads. Through that eye they peered out into invisible worlds "now I'm a sage" (5). It is the thought of Jasmine what she tells her sisters. The pain she feels and the scar will always remind her of that moment and gives her strength to give fight to achieve her dreams.

As that young woman, Jasmine is getting ready to find a husband for herself. She finds husband as she dreamt. One day her brothers brought a Sikh who had pitiless eyes, who was addressed as Sukhi, he spoke of the Khalsa and Khalistan, he was such typical person who shows his casteism. Her brothers' friend Prakash said, "This man is a danger to us and to himself"(66). Jyoti fell in love with his voice and thoughts, "It was low, gravelly, unfooled. I was prepared to marry the man who belonged to that voice" (66). It was love before first sight; it was dream about that person and Jyoti had decided to marry only with that person. Prakash was from Amritsar, about to graduate, about to send away job applications to Germany and the United States. Jane (Jyoti) says, “I couldn't marry a man 
who didn't want to speak English. To want English was to want more than you had been given at birth; it was to want the world"(68). This statement shows Jyoti as ambitious person. And later on they get married and move to a bigger city.

At the time Prakash was killed in bomb attack in a shop that time Jyoti seventeen years old only and not able to understand the situation to handle it. That unkind act of violent behavior changes everything in the life of Jasmine. She had a dream to live happily with her husband but the reality was different. After the death of Prakash, her dream was shattered. She had to live without him. First of all, she goes back to her mother's home and they live isolated as two widows for a while. But Jasmine wants to do more with her life. Jasmine thought that Prakash had taken Jyoti and created Jasmine, and Jasmine would complete the mission of Prakash -Vijh \& Wife. She gets her brothers' help to get documents for a journey to America. She takes her husband's clothes with her and intends to burn herself with them at the university he wanted to study at. Jasmine's Journey to the America describes the next turning point in her life which transforms her into a new woman

Bharati Mukherjee's novel Jasmine reveals woman as a defender. Her novels truly hold on the nature and mind set of the society. A person's life and the choices they make are eventually created by their constantly shifting conditions. In Jasmine, Mukherjee introduces us to the various changes that her novel's main protagonist, Jasmine faces.

\section{Work Cited}




\section{Surekha Patil/ Page 192-198}

Miller, Jean Baker. Towards a New Psychology of Women. New Delhi: Penguin, 1978. Print.

Mukherjee, Bharati. Jasmine. New York: Grove West publishers and distributors, 1989.print.

Mukherjeee, Meenakshi. Realism and Reality: The Novel and Society in India. Delhi: Oxford UP, 1985. Print.

Palmer, Pauline. Contemporary Women's Fiction: Narrative Practice and Feminist Theory. New York: Harvest Publishers, 1989. Print.

Peter Barry. Beginning Theory- an Introduction to Literary and Cultural Theory. Viva Books. New Delhi. 2010. Print.

\section{Dr. Jagdish Joshi \\ Professor-Director}

Human Resource Development Centre

Gujarat University

\&

Ms. Surekha R. Patil

Research Scholar (Ph.D.),

H.North Gujarat University, Patan, Gujarat.

E-mail:-surpatil@gmail.com 